\title{
A REVIEW ON EFFECT OF POTASSIUM AND CALCIUM ON DIFFERENT PARAMETERS ON PLANTS UNDER HYDROPONIC CONDITION
}

\author{
Divya Rathor ${ }^{*}$ \\ ${ }^{1}$ Department of Botany, Bioinformatics and Climate Change Impacts Management, \\ School of Science, Gujarat University, Ahmedabad, Gujarat, India.
}

Sandhya Verma ${ }^{2}$

${ }^{2}$ Department of Botany, Bioinformatics and Climate Change Impacts Management, School of Science, Gujarat University, Ahmedabad, Gujarat, India.

\author{
Hitesh Solanki ${ }^{3}$ \\ ${ }^{3}$ Department of Botany, Bioinformatics and Climate Change Impacts Management, \\ School of Science, Gujarat University, Ahmedabad, Gujarat, India.
}

\begin{abstract}
Hydroponics is a technique for better plant production in a liquid nutrient solution and without use of soil or artificial media. In this method almost all terrestrial plants, ornamental crops, vegetables, and foliage plants can be grown with their roots immersed directly to the mineral nutrient solution. This system provides better and higher crop yields, minimize the time of production and there is no weeding or cultivation required. The effect of calcium and potassium concentration affect the shoot, root and on the growth of plants. It enhance the structural, physiological as well as morphological parameters of plants. It shows the better quality and high yield of crops. This review is focused on the effect of potassium and calcium on the growth and productivity of plants. This article also evaluates the role of $K$ and $C a$ under hydroponic system to test the different parameters.
\end{abstract}

KEYWORDS : Hydroponic, Potassium, Calcium, Growth and Productivity.

\section{INTRODUCTION}

The term 'Hydroponics' was derived from Greek word 'hydro' means water and 'ponos' mean labor. Hydroponics is a modern agriculture technique that uses mineral nutrient solution rather than soil for crop production (Fraz Ahmad Khan et al.,2018). Hydroponics was found to be better alternative and can be defined as the cultivation of plants without soil, which is being commercially used in the most of the western countries. This study explores the applications of this cultivation technique and to reveal its future importance. This method can be adapted to almost all the terrestrial plants. Vegetable food crops like wheat, tomato, spinach, mint, coriander and many more plants are being cultivated in commercial scale. The construction of a hydroponic system requires an initial investment, hard work, and care. Better the yield will be, if approached as it needs. It was recommended that this technique can be adapted as a step to produce the food crops and medicinal plants to meet the global demand, to control the global warming, and there by conserving the Mother Nature for the better future. The increased population, sub-urbanization of the forest (excluding land for commercial food production), improper agricultural practice which altered the soil $\mathrm{pH}$, synthetic fertilizers, pesticides 


\section{EPRA International Journal of Research and Development (IJRD) \\ Volume: 6 | Issue: 3 | March 2021 \\ - Peer Reviewed Journal}

which drastically reduced the soil flora and fertility which made a quench for the new alternative technique for obtaining the food and medicinal plants of better quality, yield and for growing fresh produce in non-arable areas of the world (Sagar J. Dholwani et al.,2018).

\subsection{Background}

In 1627, the most primitive book on soil-less culture was Sylva Sylvarum published by Francis Bacon. In 1859-65, German botanists made developments in the techniques of soil-less culture. In 1929, solution culture was promoted by William Frederick Gerick for agricultural crop production. The term "Hydroponic" was firstly introduced by the William Frederick Gerick in 1937. In 1946, English scientist W.J. Shalto Duglas introduced the Hydroponics in West Bengal India. In 1960-70, commercial hydroponics farms were developed in many countries of the world. Later, during 1980 many automatic and high-tech hydroponics farms were developed around the world (George et al, 2010; Fraz Ahmad Khan et al.,2018).

Key factors of soil less culture or hydroponics production (Figure 1) (Aatif Hussain et al.,2014).

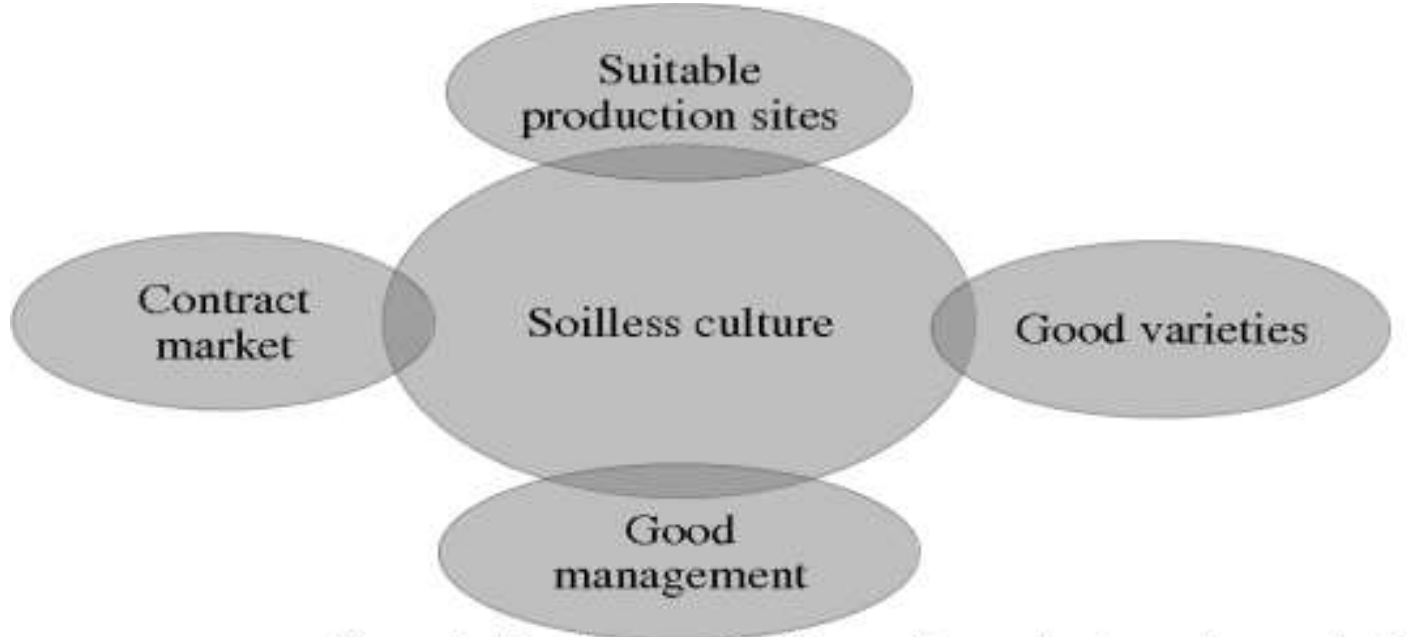

Figure 1. Key factors of soilless culture or hydroponics production

A large number of plants and crops or vegetables can grow by hydroponics system. (Nisha Sharma et al., 2018). Application of pesticides is generally avoided under hydroponics system. (Sagar J. Dholwani et al.,2018). Quality of produce, taste and nutritive value of end products is generally higher than the natural soil based cultivation. Various experimental findings outlines that leafy greens (lettuce, spinach, mint, onion and tomato etc.) can be successfully and easily grown in hydroponic systems. Lettuce and spinach are most promising species to grow in integrated hydroponics and aquaculture systems because of its higher growth and nutrient uptake capacity (Nisha Sharma et al., 2018).

Table1. The Vegetable Production under Soil-Less Culture in India.

\begin{tabular}{|c|c|}
\hline Vegetables & Production $\mathbf{( g / \mathbf { m } 2 / \text { day) }}$ \\
\hline Carrot & 56.5 \\
\hline Cucumber & 226 \\
\hline Garlic & 57 \\
\hline Ginger & 57 \\
\hline Leek & 57 \\
\hline Green Bean & 113 \\
\hline Lettuce & 226 \\
\hline Onion & 56.5 \\
\hline Peapod & 113 \\
\hline Potato & 56.5 \\
\hline Salad greens & 226 \\
\hline Tomato & 113 \\
\hline Greens & 113 \\
\hline Source: (Singh and Singh, 2012; Aatif Hussain et al.2014)
\end{tabular}




\section{SJIF Impact Factor 2021: 7.13| ISI I.F.Value:1.241| Journal DOI: 10.36713/epra2016 \\ ISSN: 2455-7838(Online) \\ EPRA International Journal of Research and Development (IJRD) \\ Volume: 6 | Issue: 3 | March 2021 \\ - Peer Reviewed Journal}

Calcium has been shown to ameliorate the adverse effects of salinity on plants (Ehret et al., 1990). Calcium is well known to have regulatory roles in metabolism (Cramer et al., 1986; B. MurilloAmador et al., 2007). Potassium is considered as most ambient macronutrients required for proper growth, development and sustainable crop yield. Most of the scientists reported that application of 60 $\mathrm{kg}$ potassium per ha is the best dose to obtain higher yield of maize. However, it depends on cultivar and soil (Muhammad Adnan et al., 2020).

Table -2. Sources of Nutrient Elements

\begin{tabular}{|l|c|c|}
\hline \multicolumn{1}{|c|}{ Source } & Element & Characteristics \\
\hline Potassium nitrate KNO3 & $\mathrm{N}, \mathrm{K}$ & Very soluble salt \\
\hline $\begin{array}{l}\text { Potassium phosphate monobasic } \\
\text { KH2PO4 }\end{array}$ & $\mathrm{P}, \mathrm{K}$ & Corrects phosphorus deficiency \\
\hline Magnesium sulfate MgSO4 & $\mathrm{S}, \mathrm{Mg}$ & Cheap, highly soluble, pure salt \\
\hline Iron chelate & $\mathrm{Fe} \mathrm{Cit}$ & Best sources of iron \\
\hline Boric acid H3BO3 & $\mathrm{B}$ & Best source of boron \\
\hline Calcium nitrate Ca(NO3)2 & $\mathrm{N}, \mathrm{Ca}$ & Very soluble salt \\
\hline
\end{tabular}

\section{EFFECT OF POTASSIUM ON GROWTH AND PRODUCTIVITY}

Potassium (K) is one of the most important elements required in large amounts for normal plant growth and development. While involved in many physiological processes, potassium's impact on water relations, photosynthesis, assimilate transport and enzyme activation can have direct consequences on crop productivity. Potassium can be applied as many forms and at different concentration. When potassium uptake is lower than demand, foliar potassium is mobilized to the fruit, to the detriment of plant growth and fruit set and quality (Besford and Maw et al., 1975; Mohsen Kazemi et al., 2014). Intensive research has been done to investigate the effects of $\mathrm{K}$ on fruit quality of vegetables grown in hydroponics, showing the significance of $\mathrm{K}$ in the nutrition of these crops (Kreij et al.,1999; Lin et al., 2004) found that increasing potassium levels significantly increased the concentration of total sugar, total soluble solids, glutamic acid, aspartic acid, alanine, and volatile acetate of muskmelon (Mohsen Kazemi et al.,2014).

Aside from that the foliar application of $\mathrm{KNO} 3$ has shown beneficial effects on growth, nutrients concentration, NRA and soluble proteins of sunflower and safflower plants, irrespective to their growth under non saline or saline conditions (Nusrat Jabeen et al., 2011). The most limiting macronutrient element is potassium which exhibited the adversely reduction of plant growth patterns in Japanese mint when compared with plants grown under the complete nutrient solution. Omission of potassium may also induce the oxidative stress condition which disrupts cell membrane stability and chlorophyll apparatus. The findings reported herein will be valuable to support optimal cultivation Japanese mint cultured in the hydroponic system (Chananchida Janpen et al.,
2019). The effect of potassium (KC) concentration on the nutritional quality and yield of pepper fruits was evaluated. Pepper (Capsicum annuum L.) plants were grown in a controlled environment greenhouse under hydroponic conditions with different nutrient solutions obtained by modifying the Hoagland solution to achieve different KC concentrations. Potassium nutrition affected fruit yield parameters more than vegetative biomass in pepper plants (M. Ángeles Botella et al., 2016). The effective concentration of $\mathrm{K}$ has shown effective improvement of fruit yield and quality seems to be at higher concentration in tomato (Mohsen Kazemi et al., 2014).

Akram M. Studied the response of maize to potassium and reported that increase in potassium levels the maize showed an increase in yield constituents. The maize exhibited maximum yield when potassium was used (a) $125 \mathrm{~kg}$ ha-1 as compared to the control treatment. They also concluded that potassium @ $125 \mathrm{~kg}$ ha-1 produced the economical yield of maize hybrids.( Akram M. et al., 2010; Muhammad Adnan et al., 2020)

\section{EFFECT OF CALCIUM ON GROWTH AND PRODUCTIVITY}

Calcium (Ca) is an essential macro-element and it is also a very important determinant of plant growth and production. Calcium is a highly mobile element and plays many crucial roles in plant membrane structure and function for forming abundant vegetative mass. It contributes to maintenance of cell membrane stability and wall structure (Wissem HAMDI et al., 2015). Foremother Ca deficiency has been linked to many disorders especially, such as brown center, hollow heart that was thought to be related to tuber Ca level. (Wissem HAMDI et al., 2015; Ozgen et al., 2003) Whereas (Arvin et al., 


\section{SJIF Impact Factor 2021: 7.13| ISI I.F.Value:1.241| Journal DOI: 10.36713/epra2016 ISSN: 2455-7838(Online) \\ EPRA International Journal of Research and Development (IJRD) \\ Volume: 6 | Issue: 3 | March 2021 \\ - Peer Reviewed Journal}

2005) revealed that increasing plant $\mathrm{Ca}$ has been shown to enhance resistance to plant tissue macerating bacterial phytopathogens. It also enhances the structural integrity of cell walls and membranes. Calcium can be applied as calcium chloride, calcium nitrate, calcium sulphate and lime Studies by (Ahmad et al.,2009) showed that calcium nitrate was highly soluble and more effective in increasing $\mathrm{Ca}$ concentration in solution. (Wissem HAMDI et al., 2015).

The effect of CaSO 4 increases the fruit yield and quality of strawberry in saline condition (M. Khayyat et al., 2007).

The effects of calcium and potassium level on the plant growth and severity of endive (Cichorium endivia L., cv. Green Curled) mainly affected the upper part of endive plants and reduced leaf area. However, when salinity combined with either K- or Ca-enrichment, the negative impact of salinity on plant growth was reversed. $\mathrm{K}$ - and $\mathrm{Ca}$ - enriched, plants did not differ in plant biomass, leaf/root ratio, leaf fresh weight, leaf number, and root length. (Tzortzakis N.G. et al., 2010).

Presence of calcium increases the life of flowers such as rose, and prevents cut flower rose from opening prematurely. With the use of calcium, such flowers may be an increase in their life cycle by preventing early blossoming of flower buds. Calcium is also beneficial in preventing the early withering of the leaves and would also reduce the atmospheric factors that can also cause withering of the plant leaves. Increasing the concentration of calcium in lilium nutrition caused to increase all growth indices particularly plant height, stem and flower diameter, bud numbers, vase life of cut flowers (N. Seyedi et al., 2012).

\section{CONCLUSION}

As condition of plant growing in soil is becoming difficult because the industry expect to grow intensely in future also. The hydroponic technique is the better option to increase the production of yield. By this technique food security of our country can be secured. Application in influence of $\mathrm{K}$ increasing in crop yield and quality at higher concentration show the better results. Added calcium in the nutrient solution may ameliorate and beneficial for crops because it improve growth and productivity of plants. The effective concentration of calcium and potassium as a source has positive response on morphological parameters of the plant.

\section{REFERENCES}

1. Janpen, C., Kanthawang, N., Inkham, C., Tsan, F. Y., \& Sommano, S. R. (2019). Physiological responses of hydroponically-grown Japanese mint under nutrient deficiency. PeerJ, 7, e7751.

2. Shrestha, A., \& Dunn, B. (2010). Hydroponics.
3. Schwarz M. 1995. Soilless culture management. Berlin: Springer.

4. Jones Jr, J. B. (2016). Hydroponics: a practical guide for the soilless grower. CRC press.

5. Khan, F. A. A. (2018). A review on hydroponic greenhouse cultivation for sustainable agriculture. International Journal of Agriculture Environment and Food Sciences, 2(2), 59-66.

6. George P. (2010). A Brief History of Hydroponics, http://ezinearticles.com. (Last cited on 2010 Dec 28).

7. Dholwani, S. J., Marwadi, S. G., Patel, V. P., \& Desai, V. P. (2018). Introduction of Hydroponic system and it's Methods.

8. Beibel, J. P. (1960). Hydroponics-The Science of Growing Crops Without Soill. Florida Department of Agric. Bull, 180.

9. Hochmuth, G. J., \& Hochmuth, R. C. (2001). Nutrient solution formulation for hydroponic (perlite, rockwool, NFT) tomatoes in Florida. HS796. Univ. Fla. Coop. Ext. Serv., Gainesville.

10. Bridgewood, L. (2003). Hydroponics: Soilless gardening explained. Ramsbury, Marlborough, Wiltshire: The Crowood Press Limited.

11. Hussain, A., Iqbal, K., Aziem, S., Mahato, P., \& Negi, A. K. (2014). A review on the science of growing crops without soil (soilless culture)-a novel alternative for growing crops. International Journal of Agriculture and Crop Sciences, 7(11), 833.

12. Sharma, N., Acharya, S., Kumar, K., Singh, N., \& Chaurasia, O. P. (2018). Hydroponics as an advanced technique for vegetable production: An overview. Journal of Soil and Water Conservation, 17(4), 364-371.

13. Ehret, D. L., Redmann, R. E., Harvey, B. L., \& Cipywnyk, A. (1990). Salinity-induced calcium deficiencies in wheat and barley. Plant and soil, 128(2), 143-151.

14. Cramer, G. R., Läuchli, A., \& Epstein, E. (1986). Effects of $\mathrm{NaCl}$ and $\mathrm{CaCl} 2$ on ion activities in complex nutrient solutions and root growth of cotton. Plant Physiology, 81(3), 792-797.

15. Murillo-Amador, B., Yamada, S., Yamaguchi, T., Rueda-Puente, E., Ávila-Serrano, N., GarcíaHernández, J. L., ... \& Nieto-Garibay, A. (2007). Influence of calcium silicate on growth, physiological parameters and mineral nutrition in two legume species under salt stress. Journal of Agronomy and Crop Science, 193(6), 413-421.

16. Sardare, M. D., \& Admane, S. V. (2013). A review on plant without soilhydroponics. International Journal of Research in Engineering and Technology, 2(3), 299-304.

17. Singh, S. and Singh, B. S.. - Hydroponics - A technique for cultivation of vegetables and medicinal plants. In. Proceedings of 4th Global conference on -Horticulture for Food, Nutrition and Livelihood Options Bhubaneswar, Odisha, India. p.220. (2012)

18. Kazemi, M. (2014). Effect of gibberellic acid and potassium nitrate spray on vegetative growth and reproductive characteristics of tomato. Journal 


\section{EPRA International Journal of Research and Development (IJRD)}

of Biological \& Environmental Sciences, 8(22), 1-9.

19. Akram, M., Ashraf, M. Y., Ahmad, R., Rafiq, M., Ahmad, I., \& Iqbal, J. (2010). Allometry and yield components of maize (Zea mays L.) hybrids to various potassium levels under saline conditions. Archives of Biological Sciences, 62(4), 1053-1061.

20. Adnan, M. (2020). Role of potassium in maize production: A review. Op Acc J Bio Sci Res, 3(5), $1-4$.

21. Besford, R. T., \& Maw, G. A. (1975). Effect of potassium nutrition on tomato plant growth and fruit development. Plant and soil, 42(2), 395-412.

22. Kreij, C. D. (1999). Production, blossom-end rot, and cation uptake of sweet pepper as affected by sodium, cation ratio, and EC of the nutrient solution. Gartenbauwissenschaft, 64(4), 158-164.

23. Duo, L., \& Danfeng, H. (2003). Effects of potassium levels on photosynthesis and fruit quality of muskmelon in medium culture. Acta Horticulturae Sinica, 30(2), 221-223.

24. Hamdi, W., Helali, L., Beji, R., Zhani, K., Ouertatani, S., \& Gharbi, A. (2015). Effect of levels calcium nitrate addition on potatoes fertilizer. International Research Journal of Engineering and Technology, 3(2), 2006-2013.

25. Ozgen, S., Ozgen, M., \& Palta, J. P. (1999). 556 Influence of Supplemental Calcium Fertilization on Potato Tuber Size and Tuber Number. HortScience, 34(3), 542B-542.

26. Arvin, M. J., Habib, A., \& Donnelly, D. J. (2005). Effects of calcium concentrations in medium on microtuberization of potato (Solanum tuberosum L.). Iranian Journal of Biotechnology, 3(3), 152156.

27. Jenkins, P. D., \& Mahmood, S. (2003). Dry matter production and partitioning in potato plants subjected to combined deficiencies of nitrogen, phosphorus and potassium. Annals of applied biology, 143(2), 215-229.

28. Ahmad, M. S. A., Javed, F., Javed, S., \& Alvi, A. K. (2009). Relationship between callus growth and mineral nutrients uptake in salt-stressed Indica rice callus. Journal of plant nutrition, 32(3), 382-394.

29. Khayyat, M., Tafazoli, E., Eshghi, S., Rahemi, M., \& Rajaee, S. (2007). Salinity, supplementary calcium and potassium effects on fruit yield and quality of strawberry (Fragaria ananassa Duch.). Am. Eurasian J. Agric. Environ. Sci, 2, 539-544.

30. Tzortzakis, N. G. (2010). Potassium and calcium enrichment alleviate salinity-induced stress in hydroponically grown endives. Horticultural Science.

31. De Pascale, S., \& Barbieri, G. (1995). Effects of soil salinity from long-term irrigation with saline-sodic water on yield and quality of winter vegetable crops. Scientia Horticulturae, 64(3), 145-157.

32. Botella, M. Á., Arévalo, L., Mestre, T. C., Rubio, $F$., García-Sánchez, F., Rivero, R. M., \& Martínez, V. (2017). Potassium fertilization enhances pepper fruit quality. Journal of Plant Nutrition, 40(2), 145-155.

33. Jabeen, N., \& Ahmad, R. (2011). Foliar application of potassium nitrate affects the growth and nitrate reductase activity in sunflower and safflower leaves under salinity. Notulae Botanicae Horti Agrobotanici Cluj-Napoca, 39(2), 172-178.

34. Seyedi, N., Mohammadi Torkashvand, A., \& Allahyari, M. S. (2015). Investigating of the effects of calcium concentration under hydroponic conditions on quantitative and qualitative growth of Lilium 'tresor. Journal of Ornamental Plants, 3(1), 19-24. 